\author{
ВПЛИВ САМОУСВІДОМЛЕННЯ СТУДЕНТІВ-ПСИХОЛОГІВ \\ ЯК СУБ'ЄКТІВ ВЛАСНОЇ ЖИТТЄТВОРЧОСТІ \\ НА МІЖОСОБИСТІСНІ СТОСУНКИ ТА ЕМОЦІЙНЕ ВИГОРАННЯ
}

\author{
THE INFLUENCE OF STUDENTS-PSYCHOLOGISTS' SELF-AWARENESS \\ AS SUBJECT OF THEIR OWN LIFE-CREATIVITY ON INTERPERSONAL \\ RELATIONSHIPS AND EMOTIONAL BURNOUT
}

УДК 159.923.2

DOI https://doi.org/10.32843/2663-

5208.2020.12-2.8

\section{Артюхіна Н.В.}

к.психол.н., доцент кафедри загальної психології і психології розвитку особистості

Одеський національний університет імені І.І. Мечникова

Сімовоник А.I.

аспірантка кафедри загальної психології і психології розвитку особистості

Одеський національний університет імені І.І. Мечникова
У статті представлено дослідження впливу самоусвідомлення студентів-психологів як суб'єктів власної життєтворчості на їхні міжособистісні стосунки та емоційне вигорання в процесі навчання. Указується, що життєтворчість - че процес, який передбачає розвинуту здібність особистості до ресрлексії, до самоусвідомлення, до роздумів над своїм життям і його побудови на основі власного світогляду. Підкреслюється, що недостатнє самоусвідомлення особистістю своїх психологічних особливостей може призводити до неадекватної витрати власних ресурсів та «емоційного вигорання», що, у свою чергу, негативно позначається на процесі життєтворчості студентів-психологів як суб'єктів власної життєдіяльності. Зазначається, що ці обставини вимагають своєчасного, профрілактичного сканування психологічного клімату навчального колективу на всіх рівнях з метою виявлення стану емоційного перенапруження в ньому. Підкреслюється, що, оскільки втілення власного проекту життя відбувається через вирішення низки послідовних життєвих завдань, до яких належить $і$ поява нових сочіальних ролей, зокрема ролі студента, завдання збереження психологічного здоров'я стає актуальним уже в процесі набуття вищої освіти, на етапі профеесійної підготовки студентів до майбутньої фрахової діяльності. Наголошується, що для студентів-психологів, які за родом своєї майбутньої діяльності повинні вміти справлятися $з$ емочійним навантаженням, мати добре розвинені навички психоемоційної саморегуляції, усвідомленого ставлення до чілей життя, черговості їх виконання, а також до способів вирішення й використання власних ресурсів, ия проблема має особливе значення. Рекомендується, як заходи психопрофрілактики й пси хокорекції емоційного вигорання на різних курсах навчання студентів-психологів використовувати різні арттерапевтичні технології, які будуть сприяти не тільки покращенню психоемоційного стану студентів, а і їхньому вільному саморозкриттю, підвищенню самоусвідомлення, розвитку творчих здібностей, придбанню навичок продуктивної міжособистісної взаємодії й усвідомленню можливості керувати своїм життям як свідомий суб'єкт власної життєтворчості. Ключові слова: особистість, суб'єкт власної життєтворчості, самоусвідомлення емоційно-поведінкові особливості особис- тості, емоційне вигорання, збереження психологічного здоров'я студентів.

The article presents the study of the influence of students - psychologists' self-awareness as subjects of their own life - creativity on interpersonal relationships and emotional burnout in the learning process. It is stated that life-creation is a process that implies a developed capacity of the individual for reflection, self-awareness, thinking about his life and constructing it on the basis of his own outlook. It is emphasized that lack of self-awareness of the personality of their psychological characteristics can lead to inadequate consumption of their own resources and "emotional burnout", which in turn negatively affects the process of students - psychologists' life-creativity as subjects of their own life. It is stated that these circumstances require timely, prophylactic, scanning of the psychological climate of the training team at all levels in order to detect the state of emotional overstress in it. It is emphasized that since the realization of one's own project of life is due to the solution of a number of consecutive life tasks, which include the emergence of new social roles, in particular the role of the student, the task of maintaining psychological health becomes relevant already in the process of higher education, at the stage of professional preparation of stu dents for future professional activity. It is stated that for students - psychologists who by their own future activity should be able to cope with emotional load, have well-developed skills of psycho-emotional self-regulation, conscious attitude to life goals, order of their fulfillment, as well as ways of solving and using their own resources, this problem is of particular importance. It is recommended to use different art-therapeutic technologies as measures of psychoprophylaxis and psychocorrection of emotional burn-out at different courses of training of students-psychologists, which will contribute not only to the improvement of the students' psycho-emotional state, but also to their free self-disclosure, increase of self-awareness, development of creative abilities, acquisition of skills of productive interpersonal interaction and awareness of the ability to manage their lives as a conscious subject of their own lives.

Key words: personality, the subject of his own life-creativity, self-awareness, emotional and behavioral features of personality, emotional burnout, preservation of students' psychological health. 
Постановка проблеми. Аналіз останніх досліджень і публікацій. Аналіз робіт С. Максименко, І. Семенова, В. Семиченко, С. Степанова, А. Сухорукова, В. Дружиніна, В. Моляко, Я. Пономарьова, Л. Сохань, І. Беха, П. Єршова, М. Кагана, М. Савчина, П. Симонова, Н. Ануфрієвої, О. Саннікової, В. Татенко, Н. Чепелєвої, Г. Костюка, А. Маслоу, П. Лушина, Н. Пов'якель, К. Роджерс, Д. Леонтьєва й інших учених свідчить про те, що поняття життєтворчості особистості пов'язується ними із цілісною, адаптованою, творчою, духовною особистістю й розвиненою індивідуальністю, здатною до саморозвитку, самоактуалізації, саморегуляції, особистісного зростання та самореалізації [1, с. 10]. Ці якості розглядаються ними як необхідні умови для свідомого проектування власного життя. Оскільки питання життетворчості особистості пов'язано з ії добрим самоусвідомленням, із розширенням її світу й життєвих відносин і можливостей, на особливу увагу заслуговують проблеми, які значно ускладнюють цей процес [3]. Саме до таких проблем належить питання «емоційного вигорання» особистості - суттєвої перепони на шляху до власної життетворчості.

Дослідження питань емоційного вигорання відбито в роботах багатьох учених, як закордонних, такі вітчизняних, середних-Г. Діон, С. Джексон, Х. Фрейденбергер, В. Шуфелі, К. Маслач, В. Бойко, Н. Водоп'янова, С. Максименко, Л. Карамушка, В. Орел, Г. Ложкін, М. Смульсон, Т. Форманюк Т. Зайчикова, О. Юр'єв, І. Кущ, М. Буріш, Н. Левицька, А. Старченкова, І. Андреєва, А. Баженова та ін. Дослідниками відзначається, що емоційне вигорання призводить до негативних наслідків, таких як погіршення психічного й фізичного здоров'я, порушення системи адаптивних міжособистісних відносин, зниження ефективності фахової діяльності, зростання негативних установок стосовно оточення, що, безумовно, негативно впливає на життєтворчі можливості особистості.

Постановка завдання. Саме ці обставини зумовили наш науковий інтерес до вивчення проблеми впливу самоусвідомлення студентів-психологів як суб'єктів власної життєтворчості на їхні взаємостосунки та емоційне вигорання в процесі навчання в динаміці 3 першого по четвертий курс. Проведення дослідження також визначалося завданням кафедри загальної психології та психології розвитку особистості ФПСР ОНУ імені І.І. Мечникова щодо вивчення особливостей самоусвідомлення й міжособистісних стосунків особистості, потенційно здатної до власної життєтворчості.

Мета статті полягає в теоретичному визначенні та емпіричному дослідженні впливу самоусвідомлення студентів-психологів на їхні взаємостосунки й емоційне вигорання в про- цесі навчання - важливого етапу на шляху їхньої власної життєтворчості.

Збереження психологічного здоров'я молоді й формування особистості, здатної до власної життєтворчості та ефективної професійної діяльності $€$ надзвичайно актуальним завданням на сучасному етапі розвитку українського суспільства. Як указує Л. Сохань, життєтворчість є особливою й вищою формою прояву творчої природи людини, духовно-практичною діяльністю особистості, спрямованою на творче проектування та здійснення її життєвого проекту [5]. Сама здатність до власної життєтворчості зосереджує в собі інтелектуальні й емоційно-вольові потенції особистості, які відбивають творчу природу й перетворювальну діяльність людини. Цей процес передбачає розвинуту здібність особистості до рефлексії, до самоусвідомлення, до роздумів над своїм життям, його побудовою на основі власного світогляду, творчого його конструювання й здійснення [3]. Але недостатнє самоусвідомлення особистості призводить до того, що людина або зливається з процесом свого існування, пливе за течією, механічно підпорядковує свою діяльність зовнішнім вимогам та обставинам, або неадекватно витрачає власні ресурси, що, у свою чергу, може призводити до її розумового, фізичного й емоційного виснаження. Цей стан у науковій літературі позначується терміном «емоційне вигорання», описується як проблематичне психофізіологічне становище, яке може проявляти себе в утомі, спустошеності, дефіциті енергії та ентузіазму, неможливості адекватно оцінювати власну діяльність і її позитивні наслідки, у схильності оцінювати негативно значення навчання в житті, що, у свою чергу, також негативно позначається на процесі власної життєтворчості особистості юнацького віку. Оскільки втілення власного проекту життя відбувається через вирішення низки послідовних життєвих завдань, до яких належать усі ті кроки людини, які змінюють її долю, серед них - поява нових соціальних ролей, зокрема ролі студента, завдання збереження психологічного здоров'я стає актуальним уже в процесі набуття вищої освіти, на етапі професійної підготовки студентів до майбутньої фахової діяльності. Найбільше це стосується студентів-психологів, чия майбутня професія пов'язана з регулярним спілкуванням 3 іншими людьми, з емоційними співпереживаннями та великою відповідальністю. Означені навантаження вже в процесі навчання у вищому навчальному закладі, в системі міжособистісних і навчальних стосунків студентів-психологів можуть призводити до емоційного вигорання. Розвитку цього стану в студентів-психологів може сприяти не тільки необхідність роботи в напруженому навчаль- 
ному ритмі з великим розумовим та емоційним навантаженням, а й недостатнє самоусвідомлення власних психологічних особливостей і ресурсів. Велике розходження між бажаним результатом і тим, що студенти мають на цьому етапі власного розвитку, відсутність належної, мріяної, винагороди (не тільки матеріальної, яка проявляє себе в оцінюванні результатів навчальної діяльності, а й психологічної, коли студенти вважають, що лише вступ до психологічного факультету дає можливість легко впоратися з усіма їхніми психологічними проблемами, що насправді не є дійсним), змушує юнаків думати, що їхні теперішні зусилля не мають цінності. Подібний стан розвивається в студентів-психологів, схильних до ідеалістичного ставлення до майбутньої роботи, разом із тим нестійких і схильних до марень. Емоційне вигорання проявляється в них у відчутті перенапруження та в почутті спустошеності, вичерпаності власних емоційних ресурсів. Студент відчуває, що не може віддаватися взаємодії з довкіллям із таким же натхненням, бажанням, як раніше. Його контакти стають формальними, знеособленими. Поступово зростає роздратування, що до певного рівня внутрішньо стримується, але з часом воно проривається назовні й призводить до міжособистісних конфліктів. У такій ситуації створення власного життєвого проекту суттєво погіршується. Вихід із неї, у підсумку, зумовлюється розвитком індивідуальної свідомості юнаків, але стійкі міжособистісні й внутрішньоособистісні конфлікти, що не знаходять засобів для вирішення й можуть призводити до стійкого емоційного навантаження й вигорання студентів, потребують допомоги зовні. Ці обставини, на нашу думку, вимагають своєчасного, профілактичного сканування психологічного клімату навчального колективу 3 метою виявлення стану емоційного перенапруження в ньому. Для студентів-психологів, які за родом своєї майбутньої діяльності повинні вміти справлятися з емоційним навантаженням, мати добре розвинені навички психоемоційної саморегуляції, усвідомленого ставлення до цілей життя, черговості їх виконання, а також до способів вирішення та використання власних ресурсів, ця проблема має особливе значення.

Виклад основного матеріалу дослідження. Дослідження проводилося на базі ФПСР ОНУ імені І.І. Мечникова. Досліджувана вибірка респондентів складається зі студентів 1, 2, 3 та 4 курсів факультету психології та соціальної роботи. Загальна кількість респондентів - 101 особа обох статей, середній вік респондентів - 20,7.

Метод психодіагностичного тестування містив такі методики: методика діагностики міжособистісних відносин Т. Лірі; тест-опитувальник для виявлення «суперечностей» вну- трішньоособистісного й професійного характеру, розроблений О. Крупенко; методика вивчення психологічного клімату колективу А. Лутошкіна; методика діагностики емоційного вигорання В. Бойко.

Проведене емпіричне дослідження «суперечностей» внутрішньоособистісного та професійного характеруза допомогою тесту О. Крупенко дало змогу отримати особистісні показники в студентів-психологів за такими діадами, як «невпевненість у собі» - «самовпевненість», «нерішучість - надмірна рішучість», «страх перед невдачею» - «геройство», «боязнь бути неправильно зрозумілим» - відсутність сприйняття співрозмовника», «недовірливість» - «необережність». Отримані результати представлені в таблиці 1.

\section{Загальний розподіл респондентів за шкалами методики О. Крупенко}

\begin{tabular}{|c|c|c|c|c|}
\hline $\begin{array}{c}\text { Домінантні } \\
\text { шкали }\end{array}$ & $\mathbf{1}$ курс & $\mathbf{2}$ курс & $\mathbf{3}$ курс & $\mathbf{4}$ курс \\
\hline $\begin{array}{c}\text { Шкала } \\
\text { А- «брак» } \\
\text { якостей }\end{array}$ & $50 \%$ & $74,1 \%$ & $58,6 \%$ & $55,2 \%$ \\
\hline $\begin{array}{c}\text { Шкала Б - } \\
\text { «надлишок» } \\
\text { якостей }\end{array}$ & $33,3 \%$ & $11,1 \%$ & $27,6 \%$ & $27,6 \%$ \\
\hline $\begin{array}{c}\text { Тенденція до } \\
\text { балансу яко- } \\
\text { стей }\end{array}$ & $16,60 \%$ & $14,8 \%$ & $13,8 \%$ & $11,1 \%$ \\
\hline
\end{tabular}

Примітка: якості шкали А - це невпевненість у собі, нерішучість, страх перед невдачею, боязнь бути неправильно зрозумілим, недовірливість; якості шкали Б - це самовпевненість, надмірна рішучість, геройство, відсутність сприйняття співрозмовника, необережність.

Отже, з таблиці видно, що на всіх чотирьох курсах респондентів-психологів відмічається переважання таких особистісних якостей, як невпевненість у собі, нерішучість, страх перед невдачею, боязнь бути неправильно зрозумілим і недовірливість. Найбільш виражено вони проявляються на другому курсі, що може свідчити про усвідомлення невідповідності бажаного й реального в уявленні студентів щодо майбутньої професії, про незадоволеність процесом навчанням через значне навантаження та велику кількість завдань для самостійної роботи, що потребують більшої відповідальності й витрати власних зусиль, а також про отриманий студентами певний негативний досвід у процесі включення до нового середовища міжособистісної взаємодії. Також привертає увагу той факт, що тенденція до балансу якостей відстежується значно меншою мірою, ніж наявність внутрішніх розбіжностей у студентів-психологів, що, у свою чергу, може не тільки негативно впливати на їхню 
життетворчість і на конструктивну взаємодію з оточенням, а й сприяти власному емоційному виснаженню.

Щодо визначення сприятливості психологічного клімату в групах респондентів-психологів нами отримані дані за методикою А. Лутошкіна, які свідчать про те, що, незважаючи на присутність у групах студентів різних точок зору щодо оцінки наявного психологічного клімату в їхньому колективі, у вибірці респондентів-психологів переважає його сприйняття як несприятливого, що, на нашу думку, може свідчити про низькі рівні самоусвідомлення й розвитку колективних відносин на всіх 4-х курсах.

Проведене емпіричне дослідження загальної динаміки уявлень студентів-психологів про себе та про своє ідеальне «Я» за допомогою методики Т. Лірі показало таке [4]. Так, на 1-му курсі психологічного факультету відбувається процес адаптації студентів до нового середовища соціальної взаємодії з проявом таких рис характеру, які дадуть змогу легшого пристосування до нового середовища, будуть сприяти опануванню новими засобами навчальної діяльності, освоєнню нового соціального статусу й ролі студента-психолога з певними правами й обов'язками. На це вказують помірні значення параметрів «егоїстичність» $(6,56)$ і «підозрілість» $(6,78)$, підвищені значення за параметрами «альтруїзм» $(8,67)$ і «підпорядкованість» $(8,5)$ у показниках «Я»-актуального. Загалом значення середньогрупового суб'єкта в показниках «Я»-актуального для 1-го курсу перебувають у межах середніх значень, за винятком показника «альтруїзм» $(8,67)$, і пограничного рівня показника «доброзичливість» $(8,0)$, що вказує на деяку тенденцію до «екстремальних» дій, які проявляються в гіпервідповідальності, у можливості жертвувати своїми інтересами, у прагненні допомогти та співчувати всім, нав'язливості у своїй допомозі та надмірно збільшеній активності стосовно оточення з прийманням на себе відповідальності за інших (що, можливо, є тільки «личиною», яка укриває «тіньові» риси особистості, оскільки показник «авторитарність» міститься на межі $(8,0)$ між адаптивною та екстремальною поведінкою). Також треба вказати на наявну різницю в показниках «Я»-актуального та «я»-ідеального. Тобто студенти уявляють себе в середньому більш авторитарними та егоїстичними, а також менш агресивними, підозрілими, підпорядкованими, залежними, доброзичливими й альтруїстичними, ніж вони $€$ насправді. Відмітимо, що така тенденція відмінності між «Я»-актуальним та «Я»-ідеальним простежується на всіх досліджуваних курсах студентів-психологів, що, у свою чергу, указує на недостатнє самоусвідомлення останніх щодо власних особистісних особливостей.
На 2-му курсі відбувається поступове зростання значень усіх параметрів «Я»-актуального, за винятком показників «підпорядкованість» та «альтруїзм», вони незначно знижуються. Тут у зону екстремальної поведінки входить показник параметр «авторитарність» $(8,52)$, що вказує на середньогрупового суб'єкта як на домінантного, енергійного, компетентного, авторитетного лідера, успішного у справах, який любить давати поради, вимагає до себе пошани. Показники: «агресивність» $(7,52)$, «підозрілість» $(7,89)$, «підпорядкованість» $(7,81)$, «доброзичливість» $(8,19)$, «альтруїзм» $(8,41)$ перебувають біля верхньої межі адаптивної поведінки. Ці обставини вказують на адаптивні процеси, які відбуваються в групі студентів-психологів.

На 3-му курсі спостерігається значне зниження всіх показників «Я»-актуального: до 5,87 бала за параметром «егоїстичність», а «Я»-ідеального до 3,87 за параметром «підозрілість». Цікаво, що в середньому студенти-психологи майже удвічі менше вважають себе підозрілими, ніж вони є за реальними значеннями. Це може свідчити про процеси індивідуалізації в міжособистісних взаєминах, тобто йде інтенсивний процес порушення раніше збудованих взаємин, який проявляється у відсутності єдності між членами групи. Кожен член групи прагне виділитися серед інших студентів.

На 4-му курсі спостерігаються інтеграційні процеси в групі студентів-психологів. Усі показники знаходяться в межах середньої інтенсивності. Показники «егоїстичність» $(7,0)$ та «агресивність» $(7,7)$ підвищуються до значень, які відзначені на другому курсі, а показники «підпорядкованість» $(8,5)$ і «залежність» $(7,3)$ є підвищеними порівняно з усіма іншими курсами. За параметром «авторитарність» $(8,2)$ середньогруповий суб'єкт проявляє себе як упевнена в собі особистість, яка не $€$ обов'язковим лідером, завзятим і наполегливим. Це особистість уперта, енергійна, критична стосовно всього оточення та суспільних явищ. Разом із тим показники середньогрупового суб'єкта за параметрами «підпорядкованість» $(8,43)$ і «залежність» $(7,5)$ також указують на існування в студентів-психологів невпевненості в собі, наявність піддатливості думці довкілля, схильність до компромісів. За параметрами «доброзичливість» $(7,18)$ та «альтруїзм» $(7,93)$ середньогруповий суб'єкт позиціює себе як особистість, схильну до співпраці й кооперації, гнучку й компромісну під час розв'язання проблем, свідомо конформну, яка підкорюється умовностям, вимогам і положенням «хорошого тону» в стосунках $з$ оточенням, а також таку, якій необхідно їм допомагати, щоб задовольнити власну потребу бути в центрі поваги, яка хоче отримати прий- 
няття й любов за умови прояву товариськості, теплоти й дружності в стосунках.

Щодо відмінностей, наявних між параметрами «Я»-актуальне та «Я»-ідеальне в респондентів усіх курсів отримані такі результати. Так, установлено, що є велика розбіжність між «Я»-актуальним та «я»-ідеальним за фактором «домінування» (39\% опитуваних) і фактором «дружність» (55,6\% опитуваних) у респондентів першого курсу. Це вказує на те, що ця кількість юнаків, які вступають на перший курс психологічного факультету, має досить приблизне уявлення про свої психологічні особливості, що, у свою чергу, презентує їх як людей, які мало задоволені собою та мають проблеми з досягненням намічених цілей у саморозвитку. у $61 \%$ респондентів першого курсу різниця між «я»-реальним та «Я»-ідеальним за фактором «домінування» має адаптивне співвідношення. За фактором «дружність» адаптивне співвідношення мають 44,4\% респондентів психологів першого курсу. Це говорить про те, що ці респонденти ставлять більш реалістичні цілі перед собою, приймають себе такими як вони є, а отже, перебувають у бадьорому, працездатному стані. Загалом 56\% респондентів першого курсу орієнтовані більше на домінування, а 44\% - на дружність.

У респондентів другого курсу значну відмінність на рівні неадаптивних значень між «Я»-актуальним та «Я»-ідеальним за фактором «домінування» мають 51,9\% опитуваних, а за фактором «дружність» $14,8 \%$ опитуваних. При цьому 70,4\% респондентів уважають себе більш панівними, ніж вони демонструють це в реальності. У 48,1\% респондентів другого курсу розбіжність між «Я»-актуальним та «я»-ідеальним за фактором «домінування» має адаптивне співвідношення. За фактором «дружність» адаптивне співвідношення демонструють 81,2\% респондентів. Загалом 29,6\% респондентів-психологів другого курсу орієнтовані більш на домінування, а 70,4\% - на дружність.

У респондентів третього курсу неоднаковість на рівні неадаптивних значень між «Я»-актуальним та «я»-ідеальним за фактором «домінування» мають $27,5 \%$ опитуваних, а за фактором «дружність» - 55,1\% опитуваних. 65,5\% респондентів уважають себе більш панівними, ніж вони є в реальності. У 72,4\% респондентів-психологів третього курсу різниця між «я»-актуальним та «я»-ідеальним за фактором «домінування» має адаптивне співвідношення. За фактором «дружність» адаптивне співвідношення демонструють 48,3\% респондентів. В актуальній ситуації 93,1\% респондентів-психологів третього курсу орієнтовані більше на домінування 3 різним ступенем його виразності, тільки 6,9\% опитуваних - на дружність. За такої кількості орі- єнтованих на домінування особистостей, які перебувають «у бадьорому, працездатному стані», міжособистісні конфлікти неминучі. Отже, відмітимо, що більша кількість міжособистісних конфліктів з підвищенням емоційного напруження відбувається саме на 3 курсі. Цей факт підтверджує те, що на цьому курсі відбуваються процеси індивідуалізації, які проявляються в зростанні показників таких параметрів, як «авторитарність», «егоїстичність» і «підозрілість».

у респондентів четвертого курсу відмінності на рівні неадаптивних значень між «Я»-актуальним та «Я»-ідеальним за фактором «домінування» мають 55,5\% опитуваних, а за фактором «дружність» - 7,4 \%опитуваних. При цьому розподіл респондентів, які вважають себе більш панівними, і тих, хто є такими насправді, поділився майже порівну: 48\% і 52\%. У 44,4\% респондентів психологів четвертого курсу різниця між «Я»-актуальним та «я»-ідеальним за фактором «домінування» має адаптивне співвідношення. За фактором «дружність» адаптивне співвідношення демонструють 92,6\% респондентів. Загалом в актуальній ситуації 48,14\% респондентів-психологів четвертого курсу орієнтовані більш на домінування, а 51,8\% - на дружність. Отже, порівняно з третім курсом на четвертому курсі відбуваються процеси стабілізації та інтеграції, які проявляються в прагненні студентів до встановлення більш доброзичливих взаємин і співпраці з оточенням.

У таблиці 2 представлені середньогрупові показники, отримані за методикою діагностики рівня емоційного вигорання В. Бойко, а саме напруження, як реакції на зовнішні та внутрішні чинники, резистенції, як заходів психологічного захисту, і виснаження як стану нервової системи студентів-психологів з першого по четвертий рік навчання [2, с. 153].

Таблиця 2

Показники емоційного вигорання в студентів-психологів

\begin{tabular}{|c|c|c|c|}
\hline $\begin{array}{c}\text { Середньогру- } \\
\text { пові значення }\end{array}$ & $\begin{array}{c}\text { Напру- } \\
\text { ження }\end{array}$ & $\begin{array}{c}\text { Резистен- } \\
\text { ція }\end{array}$ & $\begin{array}{c}\text { Висна- } \\
\text { ження }\end{array}$ \\
\hline 1 курс & 30,8 & 56,5 & 32,3 \\
\hline 2 курс & 49,9 & 68,1 & 46,2 \\
\hline 3 курс & 44,1 & 62,4 & 45,7 \\
\hline 4 курс & 50,5 & 69,5 & 55,6 \\
\hline
\end{tabular}

Із цієї таблиці видно, як відбувається зростання показників напруження від несформованої фази на 1-му курсі до фази в стадії формування на 2 та 4 курсах. Незважаючи на деяке зниження, що відбувається на 3-му курсі, показники напруження також знаходяться в стадії формування. Найбільшого виснаження респонденти досягають на 4 курсі, але все ж 
таки показники знаходяться в стадії формування. Що стосується показників резистенції, то вони є результатом уже сформованої стадії від другого до четвертого курсів.

Також дослідження за методикою В. Бойко показало, як відбувається зростання ознак вигорання в студентів-психологів від першого до четвертого курсів. Так, якщо на першому курсі привертає увагу 1 ознака, то на другому це вже 3 ознаки, на третьому їх кількість зростає до 5, а на четвертому вона досягає 7 ознак.

Отже, з 12 ознак «вигорання» на першому курсі найбільш вираженим і панівним є вже сформована ознака «емоційно-моральної дезорієнтації» $(17,1)$. Вона є не тільки показником недостатнього самоусвідомлення особистості, а й причиною погіршення взаємин з оточенням унаслідок неадекватної реакції. Досить часто студенти використовують такий механізм психологічного захисту, як проекція, перекладаючи відповідальність за власні провини на оточення, замість їх визнання.

Домінування симптомів «тривоги й депресії» $(16,6)$, а також «розширення сфери економії емоцій» $(22,0)$ та «редукції професійних обов'язків» $(16,7)$ відбувається вже на 2-му курсі. «Редукція професійних обов'язків» проявляється в спрощенні, усуненні обов'язків, які потребують емоціональних витрачань. Студенти знаходять шляхи мінімізації зусиль на навчанні, наростає скептичне ставлення до знань у процесі навчання через уповільнення переходу знань у навички, а також через недостатність практичної діяльності.

Ознака «переживання психотравмувальних обставин» $(13,4)$ найбільше проявляє себе на 3 курсі, оскільки саме в цей навчальний період виникають проблеми в освоєнні професійної інформації через величезний обсяг матеріалу, який $є$ необхідним для майбутнього професіонала, а також через поглиблення міжособистісних конфліктів. Відбувається зростання незадоволеності собою, що, на нашу думку, сприяє домінуванню «неадекватного вибіркового емоційного реагування» $(19,7)$, сформованості ознак «розширення сфери економії емоцій» $(17,9)$ та «емоційного дефіциту» $(16,4)$, коли респонденти обмежують емоціональну віддачу внаслідок вибіркового реагування в ході буденних контактів. Дії студентів підкоряються емоційному девізу: «Хочеться - не хочеться». При цьому студентам найчастіше здається, що вони діють належним чином. Проте в спілкуванні вони можуть проявляти емоційну черствість, неввічливість, байдужість. Недоречне обмеження спектру та сили включення емоцій в особистісну комунікацію сприймається партнерами по взаємодії як зневага до їхньої особистості, тобто переноситься в галузь моральних оцінок. Рідше позитивні емоції проявляються на короткий час, а все частіше відчуваються негативні. Ознаку «емоційного дефіциту» доповнюють різкість, грубощі, дратівливість, образи, примхи в міжособистісних взаєминах. Також привертають до себе увагу симптом «психосоматичні та психовегетативні порушення», який досягає максимуму саме на 3 курсі. Студенти нерідко говорять про те, що 3 курс є найбільш складним, у них виникає страх не впоратися із заданим матеріалом. Їх турбує написання дипломної роботи, майбутнє працевлаштування, поява особистого життя. Отже, нам видається, підвищення ресурсних сил студентів з метою покращення та стабілізації їхнього емоційного стану $є$ необхідним саме на третьому курсі.

Ознаки «незадоволеність собою» $(13,5)$, «загнаність у кут» $(12,6)$ та «особистісне відчуження» $(14,6)$ є найбільш вираженими в студентів-психологів на 4-му курсі, але це симптоми, які знаходяться в стані складання. Вони ще остаточно не сформовані, хоч видна їх динаміка, яка прогресує. У респондентів наявні конфлікти внутрішнього й зовнішнього характеру, є цілі, які не досягнуті, що, у свою чергу, призводить до посилення психічної енергії: працює мислення, діють плани, установки, смисли, підключаються образи належного й бажаного. Але проблеми з майбутнім працевлаштуванням за обраною спеціальністю або не розв'язані внутрішньоособистісні питання можуть призвести до знецінення власних зусиль, до переживання відчуття «загнаності в кут», коли процеси власної життєтворчості майже зупиняються. Це, безумовно, позначається на взаєминах із довкіллям. Відбувається часткова втрата інтересу до людини як суб'єкта професійної діяльності. Він сприймається як предмет, як об'єкт маніпуляцій: із ним доводиться щось робити. Але вже сформовані симптоми «емоційний дефіцит» $(16,2)$, «емоційне відчуження» $(16,4)$ і «редукція професійних обов'язків» $(16,2)$ указують на наявність повної або часткової втрати інтересу до оточення та бажання полегшити чи скоротити обов'язки, які вимагають емоційних витрат. Студенти прагнуть до психологічного комфорту, прагнуть за допомогою наявних засобів знизити тиск зовнішніх обставин. Респонденти обмежують емоційну віддачу, вибірково реагуючи на ситуацію, на суб'єктів діяльності, неадекватно «економлять» на емоціях. До студентів приходить відчуття, що емоційно вони вже не можуть допомагати суб'єктам своєї діяльності.

Кореляційний аналіз особливостей впливу особистісних і міжособистісних чинників на емоційне вигорання студентів-психологів у навчальному процесі за Спірменом показав, що існує позитивна кореляція на рівні значущості $p<0,01$ між стилем поведінки, що домінує у взаєминах, і проявом «надлишкової» 
кількості якостей особистості з метою запобігання внутрішньоособистісним і професійним суперечностям $(0,491)$. Незважаючи на те що надлишок якостей дає респондентам змогу деякий час активніше боротися з розбіжностями внутрішньоособистісного й професійного характеру, можливо, ховати їх наявність від себе, це не призводить до запобігання емоційному вигоранню, оскільки потребує застосування додаткових емоційних зусиль. У цьому контексті треба підкреслити, що збалансовані якості не тільки запобігають емоційному вигоранню студентів, а й позитивно впливають на самоусвідомлення й процес свідомої життетворчості взагалі. Також визначена негативна кореляція на $1 \%$ рівні між психологічним кліматом у колективі та проявом фаз «напруження» (-0531) i «виснаження» $(-0,535)$ на 1-му курсі й між психологічним кліматом і фазою «резистенція» $(-0,403)$ на 2-му курсі. Це говорить про те, що збільшення показників напруження, резистенції й виснаження в студентів призводить до погіршення психологічного клімату в цих групах.

Позитивна кореляція на $1 \%$ рівні на 1-му і 3-му курсах між недоліками суперечностей внутрішньоособистісного характеру та проявом фази «резистенція» $(0,526$ і 0,4 відповідно) свідчить про те, що підвищення показників невпевненості, нерішучості, страху перед невдачею, боязні бути неправильно зрозумілим у студентів-психологів посилює прояви фази «резистенція» в емоційному вигорянні. Негативний кореляційний зв'язок, виявлений на 3 курсі між стилем поведінки, що домінує в міжособистісних взаєминах, і психологічним кліматом у колективі $(-0,471)$, підтверджує, що посилення прояву панівного стилю поведінки в міжособистісних взаєминах зумовлює погіршення психологічного клімату в колективі. Позитивні кореляційні зв'язки між домінуванням і напруженням на другому курсі $(0,735)$ і дружелюбністю й напруженням у міжособистісних взаєминах на першому $(0,401)$ та другому $(0,401)$ курсах, а також дружністю й резистенцією на першому $(0,446)$, другому $(0,446)$ і третьому $(0,429)$ курсах свідчать про те, що посилення прояву таких стилів поведінки, як панівний і дружній, у міжособистісних взаєминах підсилює прояв фаз «напруження» та «резистенція» в емоційному вигоранні студентів психологічного факультету. Усе це пояснює, чому вже з 2 курсу в студентів-психологів переважним стає симптом «розширення сфери економії емоцій». Це відбувається з метою запобігання емоційному вигоранню. Свого максимального значення цей симптом набуває на 4-му курсі. Отже, можна сказати, що студенти на четвертому курсі психологічного факультету відчувають себе пересиченими людськими контактами, що, у свою чергу, призводить до того, що після закінчення навчального закладу не всі вони працюють за фахом.

Висновки з проведеного дослідження. Отже, дослідження особливостей впливу особистісних і міжособистісних чинників на емоційне вигорання студентів-психологів у процесі навчання свідчить про те, що тріада «особистісні чинники - міжособистісні чинники - процес навчання» безпосередньо впливає на розвиток емоційного вигорання студентів-психологів. Однак розвиток самоусвідомлення в студентів і своєчасне застосування засобів виявлення, психопрофілактики й психокорекції емоційного вигорання на різних курсах буде сприяти значному зниженню його патогенного впливу на когнітивну, емоційну та поведінкову сфери студентів, що, у свою чергу, підвищить їхні власні життєтворчі можливості. Як заходи психопрофілактики й психокорекції емоційного вигорання студентів-психологів на різних курсах навчання рекомендується використовувати арттерапевтичні технології. Завдяки своїй екологічності вони сприятимуть не тільки покращенню психоемоційного стану студентів, а і їхньому вільному саморозкриттю, підвищенню самоусвідомлення, розвитку творчих здібностей, придбанню навичок продуктивної міжособистісної взаємодії й усвідомленню можливості керувати своїм життям як свідомий суб'єкт власної життєтворчості.

\section{ЛІТЕРАТУРА:}

1. Артюхіна Н.В Базові складові життєтворчості особистості. Теорія і практика сучасної психології : збірник наукових праць / Класичний приватний університет. Запоріжжя, 2019. № 2. Т. 1. С. 10.

2. Бойко В.В. Психоэнергетика. Санкт-Петербург : Питер, 2008. 416 c.

3. Леонтьев Д.А. Жизнетворчество как практика расширения жизненного мира. 1-я Всероссийская научно-практическая конференция по экзистенциальной психологии : материалы сообщений / под ред. Д.А. Леонтьева, Е.С. Мазур, А.И. Сосланда. Москва : Смысл, 2001. С. 100-109.

4. Собчик Л.Н. Методы психологической диагностики. Диагностика межличностных отношений. Модифицированный вариант интерперсональной диагностики Т. Лири : методическое руководство. Москва, 1990. Вып. 3. 48 с.

5. Сохань Л.В. Искусство жизнетворчества. Предназначение. Жизнетворчество. Судьба : социологические очерки, социально-психологические эссе, интервью, глоссарий. Киев : Издательский Дом Дмитрия Бураго, 2010. 576 с. 